\title{
Green Product dan Keputusan Pembelian Konsumen Muda
}

\section{Green Product and Young Consumers' Purchasing Decisions}

\author{
Nia Resti Dianti ${ }^{1)}$, Eristia Lidia Paramita ${ }^{2)}$ \\ ${ }^{1,2)}$ Fakultas Ekonomika dan Bisnis, Universitas Kristen Satya Wacana, Salatiga \\ e-mail korespondensi: eristia.paramita@uksw.edu
}

\begin{tabular}{|l|}
\hline Info Artikel \\
\hline Riwayat Artikel : \\
Diterima: 15 Mei 2020 \\
Disetujui: 27 Agustus 2020 \\
Dipublikasikan: Januari 2021 \\
\hline Nomor DOI \\
10.33059/jseb.v12i1.2301 \\
Cara Mensitasi : \\
Dianti, N., R. \& Paramita, E., \\
L. (2021). Green product dan \\
keputusan pembelian \\
konsumen muda. Jurnal \\
Samudra Ekonomi dan Bisnis, \\
12(1), 130-142. doi: \\
10.33059/jseb. v12i1.2301.
\end{tabular}

10.33059/jseb. v12i1.2301.

\begin{abstract}
Tujuan dari penelitian ini adalah untuk mengetahui apakah ada pengaruh antara green product yang telah dibuat oleh perusahaan pada keputusan untuk membeli green product di konsumen muda di Indonesia, dengan menggunakan green product identification sebagai variabel moderasi. Penelitian ini menggunakan teknik analisis regresi linier berganda (MRA). Data diperoleh melalui kuesioner kepada 200 konsumen muda. Hasil penelitian ini menunjukkan bahwa green product memiliki pengaruh secara langsung yang signifikan dan positif terhadap keputusan pembelian konsumen muda. Namun saat dimasukkan variabel green product identification sebagai pemoderasi, pola hubungan tidak langsung antara green product menjadi memiliki efek positif namun tidak signifikan terhadap keputusan pembelian konsumen muda. Dengan demikian, disimpulkan bahwa keputusan konsumen muda untuk membeli green product sebenarnya ditentukan oleh kesadaran terhadap pentingnya green product, bukan green product identification.
\end{abstract}

Kata Kunci: Green Product, Green Product Identification, Keputusan Pembelian, Konsumen Muda.

\begin{tabular}{|l|}
\hline Article Info \\
\hline Article History : \\
Received: 15 May 2020 \\
Accepted: 27 August 2020 \\
Published: January 2021 \\
\hline DOI Number : \\
10.33059/jseb.v12i1.2301 \\
How to cite : \\
Dianti, N., R. \& Paramita, E., \\
L. (2021). Green product dan \\
keputusan pembelian \\
konsumen muda. Jurnal \\
Samudra Ekonomi dan Bisnis, \\
12(1), 130-142. doi: \\
10.33059/jseb. v12i1.2301.
\end{tabular}

\section{Article Info}

Accepted: 27 August 2020

DOI Number :

How to cite :

Dianti, N., R. \& Paramita, E., L. (2021). Green product dan keputusan pembelian

10.33059/jseb. v12i1.2301.

\section{Abstract}

The purpose of this study is to determine whether there is an effect between green products made by the company on the decision to buy green product among young consumers in Indonesia, using green product identification as a moderating variable. This study uses multiple linear regression analysis (MRA) techniques. Data were obtained through questionnaires to 200 young consumers. The results of this study indicate that green products have a significant and positive direct influence on the purchasing decisions of young consumers. However, when green product identification is included as the moderating variable, the indirect relationship pattern between green products has a positive but insignificant effect on the purchasing decisions of young consumers. Thus, it is concluded that the decision of young consumers to buy green products is actually determined by the awareness of the importance of green products, not green product identification.

Keywords: Green Product, Green Product Identification, Purchasing Decision, Young Consumer. 


\section{PENDAHULUAN}

Pada abad ke-21 terjadi perubahan lingkungan, dimana salah satunya disebabkan oleh gaya hidup manusia yang instan. Hal ini menimbulkan berbagai masalah seperti kerusakan ekosistem dan lingkungan yang menimbulkan level kewaspadaan masyarakat tentang ancaman masalah kesehatan dan masalah kelangsungan hidup (Kautish \& Sharma, 2019; Firmansyah et al., 2019; Bhutto et al., 2019).

Azaria \& Prawidya (2014) menjelaskan bahwa dalam 30-40 tahun terakhir sejak dikenalkan barang sintesis plastik yang menyebabkan kondisi alam mengalami perubahan secara signifikan. Indonesia saat ini menempati posisi kedua di dunia sebagai negara yang melakukan pembuangan sampah plastik ke laut Cina Selatan sebanyak 0,52 $\mathrm{kg}$ /orang/sampah (Jambeck et al., 2015). Dengan adanya masalah yang mengancam kerusakan ekosistem dan lingkungan maka masyarakat diharapkan dapat melakukan konsumsi yang berkelanjutan yang tidak berbahaya bagi lingkungan.

Pemerintah juga berupaya mendukung program penyelamatan lingkungan dengan menetapkan Peraturan Pemerintah Republik Indonesia Nomor 46 Tahun 2017 tentang Instrumen Ekonomi Lingkungan Hidup, yang isinya mendorong kementerian/lembaga/ satuan kerja perangkat daerah atau institusi menggunakan barang serta jasa ramah lingkungan hidup. Ketatnya regulasi pemerintah dan hukum lingkungan membuat instrument ekonomi lebih memperhatikan isuisu lingkungan dan pemanfaatan sumber daya alam, faktor tersebut menimbulkan konsumen yang peduli terhadap lingkungan (Khoiriyah \& Toro, 2014). Perusahaan yang mengerti tentang regulasi tersebut dan peduli terhadap isu lingkungan akan mendapatkan sebuah kesempatan dalam menerapkan strategi green marketing (Aldoko et al., 2013).
Konsep green marketing memiliki tujuan untuk memberikan sebuah kepuasan, keinginan serta hasrat di dalam memenuhi kebutuhan konsumen namun dengan tetap memperhatikan isu-isu berkaitan lingkungan (Risyamuka \& Mandala, 2015; Aulia \& Hidayat, 2018). Islam (2018) memaparkan strategi bauran green marketing ini meliputi konsumsi hijau, produk hijau (green product), pengiklanan hijau, saluran distribusi hijau dan harga hijau. Green product telah terbukti mmpu mengurangi efek samping berbahaya, mengurangi zat beracun, mengurangi masalah kesehatan, meningkatkan daur ulang, serta meningkatkan level keramahan lingkungan (Azevedo et al., 2011). Penelitian yang dilakukan Risyamuka \& Mandala (2015) menyebutkan variabel green marketing memiliki pengaruh yang signifikan terhadap keputusan pembelian green product. Selain itu, dalam penelitiannya Dimyati et al. (2018) juga menyebutkan bahwa green marketing memiliki pengaruh positif dan signifikan terhadap keputusan pembelian green product.

Penelitian ini akan berfokus pada green product, karena adanya perhatian tentang pentingnya keselamatan lingkungan dan isuisu lingkungan menyebabkan kesadaran masyarakat akan pentingnya mengkonsumsi green product (Rahayu et al., 2017; Kristiana, 2018). Penelitian milik Kanchanapibul et al. (2014) mengemukakan bahwa kaum muda menunjukkan sikap yang sangat positif terhadap produk ramah lingkungan dan akan mendorong kegiatan pembelian kembali mereka di masa depan. Sementara itu hasil penelitian menurut Yadav \& Pathak (2016) mengemukakan bahwa konsumen muda India memiliki sikap positif terhadap pembelian produk ramah lingkungan untuk penggunaan masa depan.

Penelitian mengenai konsumen muda juga dilakukan oleh Waemustafa et al. (2015), dimana hasil penelitian tersebut memberikan 
kesimpulan bahwa konsumen muda sadar akan kepedulian terhadap lingkungan, namun mereka tidak menunjukan aksi dalam perilaku ramah lingkungan. Penelitian Bhutto et al. (2019) menyebutkan bahwa konsumen muda di area Tiongkok sangat peduli terhadap lingkungan dan mengarahkan niat untuk membeli green product. Penelitian ini memodifikasi dari penelitian Yadav \& Pathak (2016) serta Kanchanapibul et al. (2014) untuk melihat bagaimana pengaruh antara green product dan keputusan pembelian kalangan konsumen muda, dan menambah variabel green product identification sebagai variabel moderasi (Rahnama \& Rajabpour, 2016; Dangelico \& Pontrandolfo, 2010).

Keputusan pembelian merupakan suatu usaha, dimana seorang konsumen menentukan produk yang akan dibeli, yang diakhiri dengan pembelian produk tersebut (Hidayat, 2020). Dari beberapa penelitian sebelumnya sudah mengemukan bahwa kaum muda memiliki peran lebih terhadap perlindungan keselamatan lingkungan, dan mengemukakan bahwa konsumen akan terlebih dahulu menentukan produk yang akan dibeli sebelum menentukan keputusan pembelian. Penelitian ini memiliki tujuan menganalisis bagaimana pengaruh green product dan keputusan pembelian konsumen muda (konsumen yang memiliki rentang usia 18 tahun - 26 tahun) dengan green product identification sebagai variabel moderasi. Penelitin ini juga ingin melakukan penelitian tentang green product dan keputusan pembelian konsumen muda di Indonesia karena belum begitu banyak penelitian tentang pengaruh green product terhadap keputusan pembelian di dalam segmen konsumen muda.

Oleh karena itu, tujuan dari penelitian ini adalah untuk mengetahui adakah pengaruh antara green product yang telah diciptakan oleh perusahan terhadap keputusan pembelian green product pada konsumen muda di
Indonesia dengan adanya green product identification. Manfaat penelitian ini dapat membantu perusahaan lebih mengetahui bagaimana antusias dari konsumen muda dengan diciptakan green product dan dapat membantu perusahaan untuk mengetahui tipe green product yang diminati konsumen.

\section{Green Product}

Green product menurut Firmansyah et al. (2019) adalah suatu produk yang tidak menimbulkan kerusakan terhadap lingkungan dan sumber daya alam, serta tidak menimbulkan sebuah polusi. Menurut Shaputra (2013), terciptanya green product seharusnya mempertimbangkan aspek lingkungan di dalam kehidupan sehingga dapat meminimalisir dampak buruk pada kondisi alam. Green product berkembang dari adanya peningkatan masalah mengenai pemanasan global, polusi, dan limbah, Oleh karena itu, konsumen menerjemahkan masalah lingkungan menjadi komitmen yang kuat untuk membeli produk ramah lingkungan (Maichum et al., 2016; Awan \& Wamiq, 2016). Green Product tidak berbahaya bagi kesehatan manusia, atmosfer, dan lingkungan. Kepercayaan yang paling dipegang mengenai green produt adalah produk yang dihasilkan akan lebih sehat dan selalu memperhatikan tentang keselamatan lingkungan (Khoiriyah \& Toro, 2014).

Green product menggambarkan produk yang melindungi ataupun meningkatkan lingkungan alami, konservasi energi, dan pengurangan atau eliminasi agen beracun, polusi, dan limbah (Maichum et al., 2017; Azad \& Laheri, 2014). Rahnama \& Rajabpour (2016) mengkategorikan green product menjadi empat tipe. Tipe pertama adalah produk tidak mengandung unsur yang berbahaya saat dikonsumsi, dan produk itu dapat membantu melestarikan lingkungan tanpa menghasilkan sebuah polusi. Tipe kedua adalah memiliki efisiensi dalam 
penggunaan energi, dimana green product lebih hemat daripada produk konvensional lainnya (Dangelico \& Pontrandolfo, 2010). Tipe ketiga adalah produk yang terbuat dari bahan baku yang menyediakan fungsionalitas daur ulang; serta tipe keempat adalah produk dengan teknologi proses produksi yang digunakan memiliki sifat ramah lingkungan (Dangelico \& Pontrandolfo, 2010).

\section{Keputusan Pembelian}

Keputusan pembelian adalah keputusan dimana seorang konsumen merasa tertarik pada sebuah produk dan ingin membeli, memiliki, mencoba dan menggunakan produk itu (Marlius, 2017). Keputusan pembelian yang diambil oleh konsumen merupakan beberapa kumpulan keputusan yang sudah dipikirkan oleh konsumen (Ridwan et al., 2018). Menurut argumen Atmaja \& Utami (2017), konsumen dalam proses menetapkan keputusan pembelian akan melibatkan aktivitas secara fisik dan mental. Aktivitas secara fisik yaitu aktivitas yang berhubungan dengan proses pengambilan keputusan pembelian, sedangkan aktivitas mental adalah penilaian yang ditetapkan oleh konsumen atas produk tersebut sesuai dengan kriteria.

Kemajuan perusahaan ditentukan melalui keputusan pembelian, karena makin besar keputusan pembelian yang dilakukan konsumen akan membantu pihak perusahaan mendapatkan profit lebih besar (Gunawan \& Susanti, 2015). Proses penentuan keputusan pembelian menurut Kotler \& Armstrong (2010) dibagi menjadi lima, yaitu pengenalan kebutuhan, pencarian informasi, evaluasi alternatif, keputusan pembelian, dan perilaku setelah pembelian. Proses yang dilakukan konsumen dalam pengambilan keputusan dalam pembelian produk akan dipengaruhi kepribadiannya, gaya hidup, usia serta pendapatan (Wahyuni, 2008).

\section{Konsumen Muda}

Menurut Hume (2010), konsumen muda adalah konsumen yang tidak hanya peduli dengan situasi atau kondisi saat ini, tetapi juga memperhatikan dampak di masa depan. Konsumen muda diidentifikasikan sebagai segmen pasar khusus yang membentuk kelompok konsumen kuat (Hendrawan \& Zorigoo, 2019).

Yadav \& Pathak (2016) mengemukakan bahwa konsumen muda saat ini lebih cenderung membeli produk yang bersifat ramah lingkungan. Konsumen muda dapat membantu dalam penyebaran pesan mengenai lingkungan (Uddin \& Khan, 2016). Sikap lingkungan yang dimiliki oleh konsumen muda dan perilaku pembelian green product dipengaruhi oleh karakteristik altruistik, individu dan lingkungan sekitar (Uddin \& Khan, 2018). Pickett-Baker \& Ozaki (2008) melaporkan bahwa konsumen muda lebih berpikiran terbuka dan sangat mempengaruhi keputusan pembelian green product.

\section{Kajian Teoritis}

Generasi muda mulai mempromosikan perubahan yang positif seperti berbagi informasi tentang lingkungan dan konsumsi yang bertanggung jawab terhadap lingkungan (Kautish \& Sharma, 2019). Ketika konsumen sadar dampak buruk dari konsumsi yang tidak berkelanjutan terhadap lingkungan, membuat mereka menyesuaikan tindakan dengan terlibat dalam tipe perilaku pro-lingkungan.

Kesadaran lingkungan mempengaruhi perilaku pembelian ramah lingkungan di kalangan konsumen muda dengan menstimulasi mereka agar berperilaku lebih bertanggungjawab secara sosial terhadap lingkungan (Tan et al., 2019; Chen \& Chai, 2010). Hasil penelitian Tan et al. (2019) menunjukkan adanya keputusan pembelian green product di kalangan konsumen muda di Malaysia secara langsung terkait dengan 
kesadaran lingkungan, pelabelan lingkungan, iklan ramah lingkungan dan harga.

Dalam menentukan suatu keputusan pembelian, faktor produk sendiri merupakan hal yang diperhatikan (Purnama \& Adi, 2019; Rahayu et al., 2017; Uddin \& Khan, 2018). Menurut Zulaicha \& Irawati (2016), produk berpengaruh positif dan signifikan terhadap keputusan pembelian. Keseharian konsumen saat ini diindikasikan lebih memilih membeli beranekaragam green product yang sederhana ketimbang membeli produk konvensional lainnya. Dalam proses menentukan keputusan pembelian, mereka dinilai lebih mem- perhatikan waktu, situasi, serta jenisnya (Thøgersen et al., 2012; Pratiwi et al., 2018),

Berdasarkan pemikiran itu, penelitian ini menambahkan pengaruh dari green product identification sebagai variabel moderasi. Oleh karena itu, hipotesis yang dimunculkan dalam penelitian ini adalah bahwa green product identification sebagai variabel pemoderasi berpengaruh signifikan terhadap hubungan antara green product dan keputusan pembelian konsumen muda, dan memasukkan. Gambar 1 menunjukkan pola hubungan antar variabel yang dihipotesiskan tersebut.

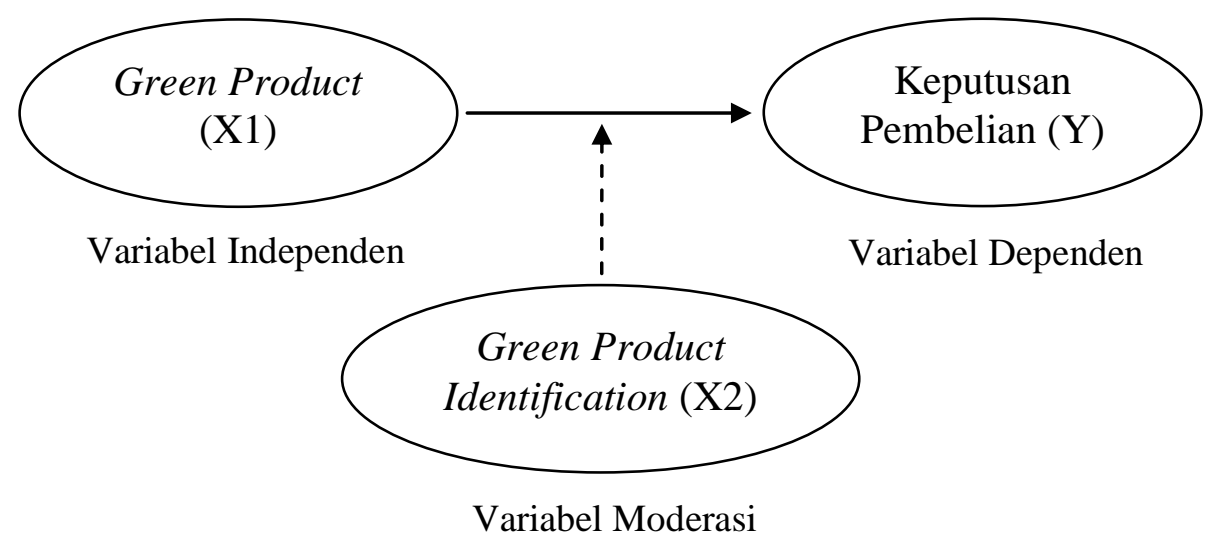

\section{Gambar 1. Kerangka Hubungan Variabel}

Sumber: Modifikasi Penelitian (Yadav \& Pathak 2016; Kanchanapibul et al., 2014).

\section{METODE PENELITIAN}

Penelitian ini menggunakan metode kuantitatif, dengan didasarkan pada sampel dalam penganalisisan data bersifat statistika dan bertujuan menguji hipotesis (Sugiyono, 2017; Ghozali, 2012). Data yang digunakan dalam penelitian ini adalah data primer, yang diperoleh melalui kuisioner.

Populasi penelitian ini adalah konsumen muda. Peneliti menentukan sampel dengan mengambil sebagian dari populasi yang dapat mewakili, yaitu sebanyak 200 responden. Teknik sampling yang digunakan adalah purposive sampling (Sugiyono, 2017). Penentuan sampel ditentukan berdasarkan tiga kriteria utama, yaitu: (1) konsumen berusia 18-26 tahun; (2) mengetahui tentang konsep green marketing dan green product; serta (3) pernah melakukan pembelian green product dan non green product.

\section{Uji Validitas dan Reliabilitas}

Uji validitas dilakukan menguji apakah instrumen yang digunakan dalam penelitian ini, yaitu kuesioner, memenuhi persyaratan validitas (Sugiyono, 2017; Sunyoto, 2012). Nilai r-hitung yang diperoleh harus diuji derajat signifikansinya membandingkannya dengan r-tabel; dimana bila r-hitung > r-tabel maka disimpulkan indikator pernyataan yang 
diajukan dinilai valid. Nilai r-tabel dari 200 responden yaitu 1,381. Hasil analisis menunjukkan nilai r-hitung untuk setiap pernyataan atas setiap variabel penelitian adalah lebih besar dari 1,381; dengan demikian dapat dikatakan bahwa kuesioner penelitian ini dinilai valid.

Berikutnya, dilakukan uji reliabilitas menggunakan kriteria nilai Cronbach alpha coefficient, dimana jika nilainya $\geq 0,70$ maka dinyatakan pernyataan di dalam kuesioner adalah reliabel (Budiman \& Riyanto, 2013). Hasil analisis menunjukkan nilai Cronbach alpha coefficient dari variabel green product sebesar 0,931 dan nilai Cronbach Alpha Coefficient dari variabel keputusan pembelian sebesar 0,943, sehingga dikatakan kuisioner penelitian ini adalah reliabel.

\section{Metode Analisis Data}

Metode analisis yang digunakan dalam penelitian ini adalah Moderated Regression Analysis (MRA). Metode atau uji interaksi ini merupakan aplikasi khusus regresi berganda linier dimana dalam persamaan regresinya mengandung unsur interaksi (perkalian dua atau lebih variabel independen) yang bertujuan untuk menguji hipotesis moderasi (Lee, 2017; Liana, 2009). Persamaan yang digunakan adalah:

$$
\begin{aligned}
& \mathrm{Y}=\mathrm{C}+\mathrm{B} 1 \mathrm{X} 1 \\
& \mathrm{Y}=\mathrm{C}+\mathrm{B} 1 \mathrm{X}_{1}+\mathrm{B} 2 \mathrm{X} 2+\ldots \ldots
\end{aligned}
$$

dimana $Y$ adalah keputusan pembelian; $C$ yaitu konstanta; $X 1$ adalah Green Product; $X 2$ yaitu Green Product Identification.

\section{HASIL ANALISIS}

\section{Karakteristik Responden}

Penelitian ini menggunakan 200 orang responden, dimana karakteristik mereka terangkum dalam Tabel 1. Berdasarkan tabel tersebut diidentifikasi mayoritas responden penelitian ini berjenis kelamin perempuan (116 orang atau 58\%), berusia antara 21 sampai 23 tahun (146 orang atau 73\%), serta memiliki pekerjaan sebagai mahasiswa/i (140 orang atau $70 \%$ ). Mayoritas responden juga lebih memilih tipe produk makanan atau green food (118 orang atau 59\%), serta telah melakukan intensitas pembelian atas green product sebanyak kurang dari tiga kali (152 orang atau $76 \%$ ).

\section{Uji Normalitas}

Uji normalitas memiliki tujuan untuk mengetahui apakah data yang kita miliki terdistribusi normal atau tidak. Pengujian ini menggunakan Kolmogorov-Smirnov test, dengan kriteria jika nilai signifikansi > 0,05 maka dikatakan data yang diuji berasal dari populasi berdistribusi normal; dan berlaku sebaliknya (Nasrum, 2018).

Hasil analisis atas data penelitian yang diperoleh menunjukkan nilai Asymp. Sig (2tailed) yang diperoleh sebesar 0,052 atau lebih besar dari 0,05. Dengan demikian bisa dinyatakan bahwa data yang digunakan dalam penelitian ini terdistribusi normal sehingga memenuhi kriteria normalitas.

\section{Hasil Analisis Regresi Sederhana}

Analisis regresi sederhana seperti dimunculkan dalam persamaan (1) bertujuan menganalisis pola hubungan antara green product (X1) terhadap keputusan pembelian konsumen muda (Y). Definisi operasional dari X1 adalah kesadaran dari konsumen terhadap pentingnya green product dalam kehidupan diri dan atau keluarganya, atau bisa diistilahkan sebagai green product awareness.

Berdasarkan hasil analisis data yang dirangkum di dalam Tabel 2, dihasilkan persamaan regresi sederhana sebagai berikut:

$$
\mathrm{Y}=13,628+0,851 \mathrm{X} 1
$$


Tabel 1. Karakteristik Responden

\begin{tabular}{|c|c|c|c|c|}
\hline No & Kriteria & Keterangan & Jumlah (org) & Jumlah (\%) \\
\hline \multirow{2}{*}{1.} & \multirow{2}{*}{ Jenis Kelamin } & Laki-laki & 84 & 42 \\
\hline & & Perempuan & 116 & 58 \\
\hline \multirow{3}{*}{2.} & \multirow{3}{*}{ Usia } & $18-20$ & 30 & 15 \\
\hline & & $21-23$ & 146 & 73 \\
\hline & & $24-26$ & 24 & 12 \\
\hline \multirow{4}{*}{3.} & \multirow{4}{*}{ Pekerjaan } & Pelajar & 5 & 2,5 \\
\hline & & Mahasiswa/i & 140 & 70 \\
\hline & & Pegawai & 36 & 18 \\
\hline & & Lainnya & 19 & 9,5 \\
\hline \multirow{3}{*}{4.} & \multirow{3}{*}{ Tipe Produk } & Food & 118 & 59 \\
\hline & & Non Food & 66 & 33 \\
\hline & & Lainnya & 16 & 8 \\
\hline \multirow{2}{*}{5.} & \multirow{2}{*}{ Intensitas Membeli } & Kurang 3 Kali & 152 & 76 \\
\hline & & Lebih 3 Kali & 48 & 24 \\
\hline
\end{tabular}

Sumber: Diolah penulis, 2020.

Tabel 2. Hasil Analisis Regresi Sederhana

\begin{tabular}{|c|c|c|c|c|c|}
\hline \multirow[t]{2}{*}{ Model } & \multicolumn{2}{|c|}{$\begin{array}{c}\text { Unstandardized } \\
\text { Coefficients }\end{array}$} & \multirow{2}{*}{$\begin{array}{c}\text { Standardized } \\
\text { Coefficients } \\
\text { Beta }\end{array}$} & \multirow[t]{2}{*}{$\mathrm{t}$} & \multirow[t]{2}{*}{ Sig. } \\
\hline & B & Std. Error & & & \\
\hline Konstanta & 13,628 & 2,402 & & 5,674 & 0,000 \\
\hline Green Product & 0,851 & 0,057 & 0,728 & 14,942 & 0,000 \\
\hline$R$ & $=$ & 0,728 & & & \\
\hline$R$-Square & $=$ & 0,530 & & & \\
\hline
\end{tabular}

Sumber: Diolah penulis, 2020.

Berdasarkan Tabel 2 serta persamaan yang terbentuk maka diketahui variabel green product $(\mathrm{X} 1=0,851)$ memiliki pengaruh yang positif terhadap keputusan pembelian konsumen muda. Selanjutnya, nilai Sig.t diperoleh sebesar 0,000 adalah lebih kecil dari 0,05; sehingga dinyatakan pengaruh dari green product atas keputusan pembelian konsumen muda bersifat signifikan.

Dengan demikian, dapat disimpulkan berdasarkan hasil analisis regresi linier sederhana bahwa green product memiliki pengaruh yang positif dan signifikan terhadap keputusan pembelian konsumen muda atas produk tersebut. Lebih jauh, derajat koefisien determinasi ( $R$-Square) menjelaskan besaran kontribusi dari green product tersebut terhadap perubahan keputusan pembelian konsumen muda adalah sebesar 53,0 persen; namun masih terdapat kontribusi dari variabel-variabel independen lainnya atas keputusan pembelian tersebut tetapi tidak dicakup dalam persamaan (1) sebesar 47,0 persen. 
Tabel 3. Hasil Analisis Moderating Regression Analysis (MRA)

\begin{tabular}{|c|c|c|c|c|c|}
\hline \multirow[t]{2}{*}{ Model } & \multicolumn{2}{|c|}{$\begin{array}{l}\text { Unstandardized } \\
\text { Coefficients }\end{array}$} & \multirow{2}{*}{$\begin{array}{c}\text { Standardized } \\
\text { Coefficients } \\
\text { Beta } \\
\end{array}$} & \multirow[t]{2}{*}{$\mathrm{t}$} & \multirow[t]{2}{*}{ Sig. } \\
\hline & B & Std. Error & & & \\
\hline Konstanta & 18,173 & 5,636 & & 3,224 & 0,001 \\
\hline Green Product & 0,769 & 0,134 & 0,658 & 5,757 & 0,000 \\
\hline Green Product Identification & $-2,720$ & 3,072 & $-0,214$ & $-0,885$ & 0,377 \\
\hline $\begin{array}{l}\text { Green Product* Green } \\
\text { Product Identification }\end{array}$ & 0,047 & 0,073 & 0,166 & 0,645 & 0,519 \\
\hline$R$ & $=$ & 0,731 & & & \\
\hline$R$-Square & $=$ & 0,535 & & & \\
\hline Adjusted R-Square & $=$ & 0,528 & & & \\
\hline
\end{tabular}

Sumber: Diolah penulis, 2020.

\section{Hasil Analisis MRA}

Langkah selanjutnya adalah melakukan analisis regresi linier berganda sebagai bagian dari MRA untuk mengetahui pengaruh green product terhadap keputusan pembelian konsumen muda dengan memasukkan green product identification sebagai variabel moderasi. Tabel 3 menunjukkan rangkuman hasil analisis MRA.

Berdasarkan hasil dalam Tabel 2 maka dapat dimunculkan modifikasi persamaan (2) menjadi sebagai berikut:

$$
\mathrm{Y}=18,173+0,658 \mathrm{X} 1-0,214 \mathrm{X} 2
$$

Hasil MRA dalam Tabel 2 serta persamaan yang terbentuk tersebut maka diketahui variabel green product $(\mathrm{X} 1=0,658)$ tetap memiliki pengaruh yang positif terhadap keputusan pembelian konsumen muda. Artinya, semakin tinggi tingkat kesadaran dalam diri konsumen muda akan pentingnya keberadaan green product bagi kehidupan mereka, maka akan semakin tinggi keputusan pembelian yang mereka lakukan atas jenis produk itu. Nilai Sig.t diperoleh sebesar 0,000 lebih kecil dari 0,05; sehingga dinyatakan pengaruh dari green product atas keputusan pembelian konsumen muda tersebut bersifat signifikan.
Sebaliknya, hasil MRA menyatakan bahwa variabel green product identification $(\mathrm{X} 2=-0,214)$ diperoleh memiliki pengaruh bersifat negatif terhadap keputusan pembelian tersebut. Hal ini berarti apabila semakin tinggi tingkat intensitas dari identification maka semakin rendah derajat keputusan pembelian konsumen muda atas green product. Nilai Sig.t diperoleh sebesar 0,377 adalah lebih besar dari 0,05; sehingga dinyatakan bahwa pengaruh dari green product identification atas keputusan pembelian konsumen muda bersifat tidak signifikan.

Selanjutnya, memperhitungkan green product identification sebagai variabel moderasi, hasil MRA menemukan nilai interaksi antara green product dengan green product identification $(\mathrm{X} 1 * \mathrm{X} 2=0,047)$ adalah positif; yang berarti bahwa adanya moderasi green product identification menghasilkan pengaruh yang positif terhadap pola hubungan antara green product dan keputusan pembelian konsumen muda. Akan tetapi, nilai Sig.t atas pola moderasi ini diperoleh sebesar 0,519 atau lebih besar dari 0,05; sehingga dinyatakan bahwa pengaruh moderasi dari green product identification atas hubungan antara green product dengan keputusan pembelian konsumen muda bersifat tidak signifikan. 


\section{Pembahasan}

Hasil penelitian ini menyatakan terdapat pengaruh green product yang positif dan signifikan terhadap keputusan pembelian konsumen muda. Mayoritas responden yang merupakan kaum perempuan dengan rentang usia rata-rata 20 sampai 22 tahun kesediaannya untuk membeli produk yang dinilai tidak mengandung racun tersebut. Selain itu, mayoritas responden menyatakan bersedia membeli produk yang ramah itu terkait upaya penyelamatan lingkungan walaupun hanya melakukan pembelian produk dilakukan kurang dari tiga kali dalam waktu sebulan.

Hasil dari penelitian ini serupa dengan penelitian Yadav \& Pathak (2016) serta Tan et al. (2019) dimana terdapat hasil yang positif terhadap pembelian green product di kalangan konsumen muda. Senada dengan hal tersebut, konsumen muda juga menunjukkan menunjukkan sikap yang sangat positif terhadap green product dan akan mendorong kegiatan pembelian kembali (Kanchanapibul et al., 2014; Pratiwi et al., 2018). Penelitian Bhutto et al. (2019) menyatakan bahwa konsumen muda sangat peduli terhadap lingkungan dan mengarahkan niat mereka untuk membeli green product.

Firmansyah et al. (2019) menjelaskan green product adalah suatu produk yang tidak menimbulkan kerusakan terhadap lingkungan dan sumber daya alam, serta tidak menimbulkan sebuah polusi. Merujuk pada pengertian itu, mayoritas responden muda menyatakan setuju bahwa konsumen tetap memperhatikan tentang keselamatan dan keseimbangan ekosistem lingkungan (hewan dan tumbuhan) ketika ingin melakukan sebuah pembelian produk. Ketika konsumen sadar dampak buruk dari konsumsi yang tidak berkelanjutan terhadap lingkungan, membuat mereka melakukan penyesuaian tindakan dengan terlibat dalam pola perilaku pro- lingkungan. Dengan demikian, kesadaran lingkungan dapat mempengaruhi perilaku pembelian yang bersifat ramah lingkungan dengan merangsang untuk dapat bertanggung jawab secara sosial terhadap lingkungan (Tan et al., 2019; Chen \& Chai, 2010; Purnama \& Adi, 2019).

Secara teoritis, penelitian ini memberi dukungan terhadap hasil penelitian milik Kanchanapibul et al. (2014) yang menyatakan bahwa kaum muda menunjukkan sikap yang sangat positif terhadap green product. Selain itu, Yadav \& Pathak (2016) juga menyatakan kelompok konsumen muda India prihatin dengan masalah lingkungan saat ini dan memiliki sikap positif terhadap pembelian produk ramah lingkungan untuk penggunaan masa depan mereka. Penelitian ini juga sejalan dengan Tan et al. (2019) mengatakan bahwa adanya sebuah keputusan pembelian green product di kalangan konsumen muda di Malaysia. Namun hasil penelitian ini tidak sejalan dengan temuan penelitian yang diperoleh Sukri et al. (2015).

Dengan menambahkan green product identification sebagai variabel pemoderasi diperoleh hasil pengaruh yang positif namun tidak signifikan dalam pola hubungan antara green product terhadap keputusan pembelian konsumen muda. Hasil ini dihubungkan dengan opini dari mayoritas responden yang menyatakan persetujuan akan melakukan pembelian produk ramah lingkungan yang dinilai tidak mengandung racun dan keinginan membeli green product yang proses produksi dan bahan baku yang ramah lingkungan.

Berdasarkan hasil-hasil penelitian itu dimana terdapat jumlah rata-rata kesetujuan terhadap green product dengan kategori tinggi, pemikiran yang muncul mengenai mengapa variabel moderasi tidak memberikan pengaruh terhadap green product dan keputusan pembelian, dapatlah dilihat dari derajat kesepakatan konsumen terhadap 
kesadaran konsep green product yang termasuk dalam kriteria tinggi. Dengan demikian dapat dikonklusikan bahwa yang mempengaruhi proses keputusan pembelian konsumen muda terhadap green product sebenarnya ditentukan oleh adanya kesadaran dari kaum konsumen muda atas pentingnya manfaat green product bagi diri dan atau keluarga mereka, dan bukanlah karena green product identification.

\section{SIMPULAN}

Berdasarkan hasil analisis penelitian maka dapat dinyatakan dua kesimpulan utama. Hasil analisis pertama menyimpulkan bahwa pengaruh langsung dari green product bersifat positif dan signifikan terhadap keputusan pembelian dari konsumen muda. Kesimpulan kedua yaitu bahwa green product identification sebagai variabel pemoderasi bersifat positif namun tidak signifikan terhadap pola hubungan antara green product dan keputusan pembelian konsumen muda.

Implikasi praktis dari hasil penelitian ini adalah dapat berkontribusi bagi strategi perusahaan dalam menciptakan green produt yang berfokus pada jenis food (makanan dan minuman), Hal ini karena penelitian ini mengidentifikasi relatif banyak konsumen memiliki antusias tinggi mengenai kesadaran tentang pentingnya green product, sehingga perusahaan sebaiknya melakukan promosi yang gencar agar konsumen lebih mengenal dan memahami tentang pentingnya green product.

Penelitian ini, bagaimanapun, memiliki keterbatasan dalam aspek bahasa instrumen penelitian, dimana ditengarai relatif banyak responden yang kurang teliti terhadap pernyataan yang ada. Bagi peneliti selanjutnya direkomendasikan sebaiknya pernyataan dalam kuisioner dibuat dengan bahasa yang lebih sederhana. Selain itu, terindikasi bahwa pembuatan green product dari bahan daur ulang tidak begitu diminati, sehingga disarankan perusahaan membuat inovasi baru untuk membuat produk daur ulang yang lebih unik (memiliki nilai pakai dan nilai estetika. Ini dapat menjadikan celah (niche) untuk melakukan penelitian dengan menggunakan obyek green product yang memanfaatkan bahan daur ulang sebagai elemen utamanya.

\section{REFERENSI}

Aldoko, D., Suharyono, S., \& Yuliyanto, E. (2013). Pengaruh green marketing terhadap citra merk dan dampaknya pada keputusan pembelian (Survei pada mahasiswa Fakultas Ilmu Administrasi 2012/2013 Universitas Brawijaya yang melakukan pembelian produk Tupperware). Jurnal Administrasi Bisnis, 40(2), 17-23. Retrieved from http://administrasibisnis.studentjournal. ub.ac.id/index.php/jab/article/view/1602

Atmaja, N. P. C. D., \& Utami, N. M. S. (2017). Analisis green marketing, psikologi dan karakteristik green consumer dan pengaruhnya terhadap keputusan pembelian produk organik di Buda Shop Bali. Jurnal Ekonomi dan Pariwisata, 12(2), 153-162. Retrieved from https://jurnal.undhirabali.ac.id/ index.php/pariwisata/article/view/244.

Aulia, A., \& Hidayat, M. (2018). Pengaruh green marketing mix terhadap keputusan pembelian rumah pada PT. Baruga Asrinusa Development Makassar. Economix, 6(1), 70-79. doi: 10.17605/ OSF.IO/T2FYP.

Awan, A. G., \& Wamiq, S. (2016). Relationship between environmental awareness and green marketing. Science International, 28(3), 2959-2963.

Azad, P. K., \& Laheri, V. K. (2014). Consumer adoption of green products and their role in resource management. Indian Journal of Commerce and Management Studies, 5(3), 22-28. Retrieved from https://ideas.repec.org/a/ aii/ijcmss/v5y2014i3p22-28.html. 
Azaria, D. P. (2014). Perlindungan lingkungan laut Samudra Pasifik dari gugusan sampah plastik berdasarkan hukum lingkungan internasional. Jurnal Hukum, O(0), 1-18. Retrieved from http://hukum.studentjournal.ub.ac.id/ind ex.php/hukum/article/view/587.

Azevedo, S. G., Carvalho, H., \& Machado, V. C. (2011). The influence of green practices on supply chain performance: A case study approach. Transportation Research Part E: Logistics and Transportation Review, 47(6), 850-871. https://doi.org/10.1016/j.tre.2011.05.017

Bhutto, M. Y., Zeng, F., Soomro, Y. A., \& Khan, M. A. (2019). Young Chinese consumer decision making in buying green products: An application of theory of planned behavior with gender and price transparency. Pakistan Journal of Commerce and Social Sciences (PJCSS), 13(3), 599-619. Retrieved from http://hdl.handle.net/10419/205269

Chen, T. B., \& Chai, L. T. (2010). Attitude towards the environment and green products: consumers' perspective. Management Science and Engineering, 4(2), 27-39. doi: 10.3968/j.mse.19130 35X20100402.002.

Budiman, \& Riyanto, A. (2013). Kapita selekta kuesioner pengetahuan dan sikap dalam penelitian kesehatan. Salemba Medika Press.

Dangelico , R., \& Pontrandolfo, P. (2010). From green product definitions and classifications to the green option matrix. Journal of Cleaner Production, 18(16-17), 1608-1628. doi: 10.1016/j. jclepro.2010.07.007.

Kartikasari, M. D., Dimyati, M., \& Sukarno, H. (2018). Pengaruh green marketing dan pengetahuan terhadap keputusan pembelian dengan mediasi minat membeli konsumen Sariayu Martha Tilaar di Kota Jember. E-Journal Ekonomi Bisnis dan Akuntansi, 5(20, 172-177. doi: 10.19184/ejeba.v5i2.8680.

Firmansyah, F., Purnamasari, P. E., \& Djakfar, M. (2019). Religiusitas, lingkungan dan pembelian green product pada konsumen Generasi Z. Iqtishoduna, 15(1), 5-10. doi: 10.18860/ iq.v1i1.5779.

Ghozali, I. (2012). Analisis multivariate dengan program SPSS. Badan Penerbit Universitas Diponegoro.

Gunawan, A. C., \& Susanti, F. (2019). Pengaruh bauran promosi dan harga terhadap keputusan pembelian produk kosmetik Maybelline di Kota Padang. INA-Rxiv Papers. doi: 10.31227/osf.io/ npjqh.

Hendrawan, D., \& Zorigoo, K. (2019). Trust in website and its effect on purchase intention for young consumers on $\mathrm{C} 2 \mathrm{C}$ e-commerce business. Jurnal Aplikasi Manajemen (JAM), 17(3), 391-399. doi: 10.21776/ub.jam.2019.017.03.02.

Hidayat, T. (2020). Analisis pengaruh produk, harga, promosi dan lokasi terhadap keputusan pembelian. Jurnal Ilmu Manajemen, 17(2), 95-105. doi: 10.21831/jim.v17i2.34783.

Hume, M. (2010). Compassion without action: Examining the young consumers consumption and attitude to sustainable consumption. Journal of World Business, 45(4), 385-394. doi: 10.1016/ j.jwb.2009.08.007.

Islam, D. (2018). Tinjauan penerapan konsep green marketing. Jurnal Pamator: Jurnal Ilmiah Universitas Trunojoyo Madura. 11(1), 10-18. doi: 10.21107/ pamator.v11i1.4436.

Jambeck, J. R., Geyer, R., Wilcox, C., Siegler, T. R., Perryman, M., Andrady, A., Narayan, R., \& Law, K. L. (2015). Plastic waste inputs from land into the ocean. Science, 347(6223), 768-771. doi: 10.1126/science.1260352.

Kanchanapibul, M., Lacka, E., Wang, X., \& Chan, H. K. (2014). An empirical investigation of green purchase behaviour among the young generation. Journal of Cleaner Production, 66, 528-536. doi: 10.1016/j.jclepro.2013. 10.062 . 
Kautish, P., \& Sharma, R. (2019). Value orientation, green attitude and green behavioral intentions: An empirical investigation among young consumers. Young Consumers, 20(4), 338-358. doi: 10.1108/YC-11-2018-0881.

Khoiriyah, S., \& Toro, M. J. S. (2014). Faktor-faktor yang mempengaruhi kesediaan membeli produk hijau. Jurnal Bisnis dan Manajemen, 1(1), 63-76. doi: 10.20961/jbm.v14i1.2686.

Kotler, P., \& Armstrong, G. (2010). Principles of marketing. Pearson.

Kristiana, I. G. A. A. D. (2018). Pengaruh green product, green price, green place, dan green promotion terhadap perilaku pasca pembelian konsumen air minum dalam kemasan di Kabupaten Bandung. Jurnal Indonesia Membangun, 17(2), 19-31. Retrieved from https://jurnal. inaba.ac.id/index.php/JIM/article/view/ 107.

Lee, Y. K. (2017). A comparative study of green purchase intention between Korean and Chinese consumers: The moderating role of collectivism. Sustainability. 9(10), 1-17. doi: 10.3390/su9101930.

Liana, L. (2009). Penggunaan MRA dengan SPSS untuk menguji pengaruh variabel moderating terhadap hubungan antara variabel independen dan variabel dependen. Dinamik, 14(2), 90-97. Retrieved from https://www.unisbank. ac.id/ojs/index.php/fti1/article/view/95.

Maichum, K., Parichatnon, S., \& Peng, K.-C. (2016). Application of the extended theory of planned behavior model to investigate purchase intention of green products among Thai consumers. Sustainability, 8(10), 1-20. doi: 10.3390/su8101077.

Marlius, D. (2017). Keputusan pembelian berdasarkan faktor psikologis dan bauran pemasaran PT. Intercom Mobilindo Padang. Jurnal Pundi, 01(01), 57-66. doi: 10.31575/jp.v1i1.9.

Nasrum, A. (2018). Uji normalitas data untuk penelitian. Jayapangus Press.
Peraturan Pemerintah Republik Indonesia. (2017). Peraturan Pemerintah Republik Indonesia nomor 46 tahun 2017 tentang instrumen ekonomi lingkungan hidup.

Pickett-Baker, J., \& Ozaki, R. (2008). Proenvironmental products: Marketing influence on consumer purchase decision. Journal of Consumer Marketing, 25(5), 281-293. doi: 10.1108/07363760810890516.

Pratiwi, N. P. D. K., Sulhaini, S., \& Rinuastuti, B.H. (2018). The effect of environmental knowledge, green advertising and environmental attitude toward green purchase intention. Russian Journal of Agricultural and Socio-Economic Sciences, 78(6), 95105. doi: 10.18551/rjoas.2018-06.10.

Purnama, P. A. I., \& Adi, N. R. (2019). Green marketing dan quality brand sebagai prediktor perilaku konsumen dan dampaknya terhadap keputusan pembelian produk. Jurnal Manajemen Bisnis, 16(1), 185-205. doi: 10.38043/ jmb.v16i1.2027.

Rahayu, L., Abdillah, Y., \& Mawardi, M. (2017). Pengaruh green marketing terhadap keputusan pembelian konsumen (Survei pada konsumen The Body Shop di Indonesia dan di Malaysia). Jurnal Administrasi Bisnis S1 Universitas Brawijaya, 43(1), 121131. Retrieved from http://administrasi bisnis.studentjournal.ub.ac.id/index.php/ jab/article/view/1705.

Rahnama, H., \& Rajabpour, S. (2016). Identifying effective factors on consumers' choice behavior toward green products: The case of Tehran, the capital of Iran. Environmental Science and Pollution Research, 24(1). 911-925. doi: 10.1007/s11356-016-7791.

Ridwan, M., Fauzi, A. D. H., \& Bafadhal, A. S. (2018). Pengaruh green product, green advertising dan green brand terhadap keputusan pembelian (Survei pada mahasiswa jurusan Ilmu Administrasi Bisnis angkatan 2013/2014 dan 2014/2015 Fakultas Ilmu Administrasi Universitas Brawijaya 
konsumen air minum kemasan merek ADES). Jurnal Administrasi Bisnis, 55(1), 80-90. Retrieved from http:// administrasibisnis.studentjournal.ub.ac. id/index.php/jab/article/view/2243.

Risyamuka, I., \& Mandala, K. (2015). Pengaruh green marketing terhadap keputusan pembelian produk hijau di Restoran Sari Organik Ubud. E-Jurnal Manajemen, 4(2), 524-543. Retrieved from https://ojs.unud.ac.id/index.php/ Manajemen/article/view/10803/0.

Shaputra, R. K. (2013). Penerapan green marketing pada bisnis produk kosmetik. Jurnal JIBEKA, 7(3), 47-53. Retrieved from https://studylibid.com/doc/117064/ penerapan-green-marketing-pada-bisnisproduk-kosmetik.

Sugiyono. (2017). Metode penelitian kuantitatif, kualitatif, dan kombinasi mixed methods. Alfabeta.

Sukri, S., Meterang, N., \& Waemustafa, W. (2015). Green marketing and purchasing decisions among teenagers: An empirical perspectives. Australian Journal of Basic and Applied Sciences, 9(37), 238-244. doi: 10.6084/m9. figshare.4043022.

Sunyoto, D. (2012). Konsep dasar riset pemasaran dan perilaku konsumen. CAPS (Center for Academic Publishing Service).

Tan, C. N. L., Ojo, A. O., \& Thurasamy, R. (2019). Determinants of green product buying decision among young consumers in Malaysia. Young Consumers, 20(2), 121-137. doi: 10.1108/YC-12-2018-0898.

Thøgersen, J., Jørgensen, A-K., \& Sandager, S. (2012). Consumer decision making regarding a "green" everyday product. Psychology \& Marketing, 29(4), 187197. doi: 10.1002/mar.20514.
Uddin, S. M. F., \& Khan, M. N. (2016). Exploring green purchasing behaviour of young urban consumers. South Asian Journal of Global Business Research, 5(1), 85-103. doi: 10.1108/sajgbr-122014-0083.

Uddin, S. M. F., \& Khan, M. N. (2018). Young consumer's green purchasing behavior: Opportunities for green marketing. Journal of Global Marketing, 31(4), 1-12. doi: 10.1080/ 08911762.2017.1407982.

Waemustafa, W., Utara, U., \& Sukri, S. (2015). Green marketing and purchasing decisions among teenagers: An empirical perspectives. Australian Journal of Basic and Applied Sciences. 9(37), 238-244. doi: 10.6084/m9. figshare.4043022.

Wahyuni, D. U. (2008). Pengaruh motivasi, persepsi dan sikap konsumen terhadap keputusan pembelian sepeda motor merek "Honda" di kawasan Surabaya Barat. Jurnal Manajemen dan Wirausaha, 10(1), 30-37. doi: 10.9744/ jmk.10.1.pp.\%2030-37.

Hidayat, T. (2020). Analisis pengaruh produk, harga, promosi dan lokasi terhadap keputusan pembelian. Jurnal Ilmu Manajemen, 17(2), 95-105. doi: 10.21831/jim.v17i2.34783.

Yadav, R., \& Pathak, G. S. (2016). Young consumers' intention towards buying green products in a developing nation: Extending the theory of planned behavior. Journal of Cleaner Production, 135, 732-739. doi: 10.1016/j.jclepro.2016.06.120.

Zulaicha, S., \& Irawati, R. (2016). Pengaruh produk dan harga terhadap keputusan pembelian di Morning Bakery Batam. Inovbiz: Jurnal Inovasi dan Bisnis, 4(2), 125-136. doi: 10.35314/inovbiz.v4i2.76. 